\title{
ASSESSING THE IMPACT OF CLIMATE CHANGE IN PONNANIYAR BASIN OF TAMIL NADU BASED ON REGCM 4.4 SIMULATIONS
}

\author{
V. Guhan ${ }^{1, *}$, V. Geethalakshmi ${ }^{1}$, R. Jagannathan ${ }^{2}$, S. Panneerselvam ${ }^{1}$, K. Bhuvaneswari ${ }^{1}$ \\ ${ }^{1}$ Agro Climate Research Centre, Tamil Nadu Agricultural University, Coimbatore - 641003 (*guhanthiran@gmail.com, \\ geetha@tnau.ac.in, panneer_selvam43@yahoo.com, bhuviagm@gmail.com) \\ ${ }^{2}$ Department of Agricultural Engineering, Paavai Engineering college, Namakkal-637018 (jagan@tnau.ac.in)
}

Commission III, WG III/10

KEY WORDS: AquaCrop, Yield, Water use efficiency (WUE), RCP 4.5, RCP 8.5

\begin{abstract}
:
Climate change induced extreme weather events such as drought and flood condition are likely to become more common and associated impacts on crop production will be more without proper irrigation planning. The present investigation was undertaken for assessing the impact of Climate change on tomato yield and water use efficiency (WUE) using AquaCrop model and RegCM 4.4 simulations. The water driven AquaCrop model was validated based on observation of field experiment conducted with four different dates of sowing $\left(1^{\text {st }}\right.$ November, $15^{\text {th }}$ November, $1^{\text {st }}$ December, $15^{\text {th }}$ December $)$ at Ponnaniyar basin, Tiruchirappalli. Validation of AquaCrop model indicated the capability of AquaCrop in predicting tomato yield, biomass and WUE close to the observed data. Seasonal maximum and minimum temperatures over Tiruchirappalli are projected to increase in the mid-century under both RCP4.5 and RCP8.5 scenarios. Maximum temperature is expected to increase up to $1.7^{\circ} \mathrm{C} / 2.5^{\circ} \mathrm{C}$ in $\mathrm{SWM}$ and $1.9^{\circ} \mathrm{C} / 2.9^{\circ} \mathrm{C}$ in $\mathrm{NEM}$ by the mid of century as projected through stabilization (RCP 4.5) and overshoot emission (RCP 8.5) pathways. Minimum temperature is expected to increase up to $1.6^{\circ} \mathrm{C} / 2.2^{\circ} \mathrm{C}$ in SWM and $1.6{ }^{\circ} \mathrm{C} / 2.1^{\circ} \mathrm{C}$ in NEM by the mid of century as projected through stabilization (RCP 4.5) and overshoot emission (RCP 8.5) pathways. Seasonal rainfall over Tiruchirappalli is expected to decrease with RCP4.5 and RCP8.5scenarios with different magnitude. Rainfall is expected to change to the tune of $-1 /-11$ per cent in SWM and $-2 /-14$ per cent in NEM by the mid of century as projected through stabilization (RCP 4.5) and overshoot emission (RCP 8.5) pathways.
\end{abstract}

\section{INTRODUCTION}

Water is essential for growing food, for household water uses, a critical input for industry, tourism and cultural purposes, and for its role in sustaining the earth's ecosystems. But this essential resource is under threat. Growing national, regional, and seasonal water scarcities in much of the world pose severe challenges for national governments and international development and environmental communities (Rosegrant et al., 2002). In the changing climate, water scarcity is an increasingly important issue in many parts of the world. This is especially the case in arid and semiarid regions, which are exposed to frequent droughts and restricted supply of good quality water limiting crop production. Insufficient water supply for irrigation will be the norm rather than the exception, and irrigation management will shift from emphasizing production per unit area towards maximizing the production per unit of water consumed (the water productivity). There is an urgent need to optimize water use in order to maximize crop yields under water deficit conditions (Fereres and Soriano, 2007). The primary objective of this study is to determine quantitatively the expected changes of water availability and Tomato yield in the Ponnaniyar basin for future climate scenarios. This gives an opportunity to define the degree of vulnerability of water resources in the Ponnaniyar basin.

\section{MATERIALS AND METHODS}

\subsection{Location}

The field experiment was conducted in a Farmers field at Ponnaniyar basin, Mugavanur village, Vaiyampatti block of Tiruchirappalli district. The experimental site is situated at $10.51^{\circ} \mathrm{N}$ latitude and $78.21^{\circ} \mathrm{E}$ longitude at an altitude of 78.17 $\mathrm{m}$ above mean sea level.

\subsection{Input requirement for setting up AquaCrop}

AquaCrop model uses a relative small number of explicit parameters and largely intuitive input variables, either widely used or requiring simple methods for their determination. Input consists of weather data, crop and soil characteristics, and management practices that define the environment in which the crop will developed.

\subsection{Impact of current climate variability on water productivity of Tomato}

To understand the impact of current variability of climate on water productivity of Tomato weather data at daily time steps for a period from 1980 to 2010 was obtained from the observatory located at Anbil Dharmalingam Agricultural College and Research Institute (ADAC\&RI), Tiruchirappalli. Climate data file was generated with entire dataset of rainfall, maximum temperature, minimum temperature, sunshine hours, wind speed and relative humidity in AquaCrop model. The simulation was performed for 31 years and extracted the required data (fruit yield, ET) from the output file and assessed the impact of climate variability on Tomato crop water 
productivity. The water driven AquaCrop model was validated based on observation of field experiment conducted with four different dates of sowing (1st November, 15th November, 1st December, 15th December) at Ponnaniyar basin, Tiruchirappalli.

\subsection{Impact of future climate projection on water productivity of Tomato}

For the impact analysis, future climate data obtained from the GCM (CCSM 4) with regional climate model namely RegCM 4.4 was used for the mid-century $(2040-2069)$ time slice based on RCP4.5 and 8.5 scenarios. AquaCrop model forced with the future climatic data and other input files were used similarly which were used with current climatic runs. In the model, the data on the $\mathrm{CO} 2$ concentration respective to $\mathrm{RCP} 4.5$ and RCP8.5 are available in the file name of RCP4-5.CO2 and RCP8-5.CO2. In.CO2 file the $\mathrm{CO} 2$ concentration is given based on IPCC data from 1902 to 2100 . In the model, defined the CO2 concentration for future scenarios by choosing.CO2 files corresponding to RCP4.5 and RCP8.5 scenarios. The data were extracted from the model simulations and analysed for evaluating the impact of climate change on water productivity in tomato.

\section{RESULTS AND DISCUSSION}

\subsection{Current climate data analysis}

Weather parameters of Tiruchirappalli region were analysed for the base period from 1980 to 2010 to understand its climatology. Annual normal rainfall of Tiruchirappalli is found to be $766 \mathrm{~mm}$ and this rainfall is received through 46 rainy days. Among the monsoons. Northeast monsoon (NEM) had higher amount of rainfall $412 \mathrm{~mm}$ received in 21 rainy days followed by Southwest monsoon (SWM) with $196 \mathrm{~mm}$ of rainfall received in 14 rainy days. Comparing the boxplots depicted in (Fig. 1). SWM shows less variability than NEM. But the quantity of rainfall received in SWM is not sufficient for crop production while NEM receives enough rainfall for raising the crops successfully.

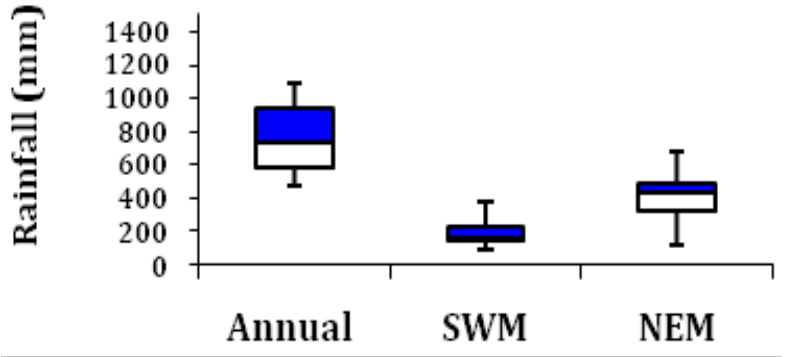

A) Baseline rainfall of Tiruchirappalli

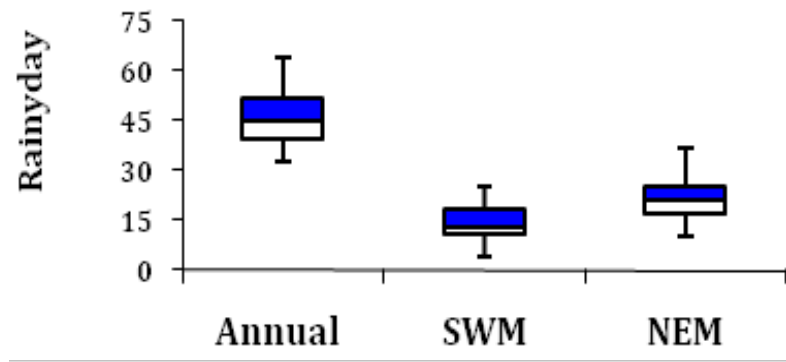

B) Baseline rainy days of Tiruchirappalli
Figure 1. Baseline rainfall and rainy days of Tiruchirappalli

Normal annual maximum temperature of Tiruchirappalli is $34.3^{\circ} \mathrm{C}$ and during SWM it is $35.5^{\circ} \mathrm{C}$ followed by NEM $30.4^{\circ} \mathrm{C}$. Normal annual minimum temperature is $20.0^{\circ} \mathrm{C}$ and that of SWM is $22.3^{\circ} \mathrm{C}$ followed by NEM $17.2^{\circ} \mathrm{C}$. In both maximum and minimum temperature. SWM has higher temperature range than NEM (Fig. 2).

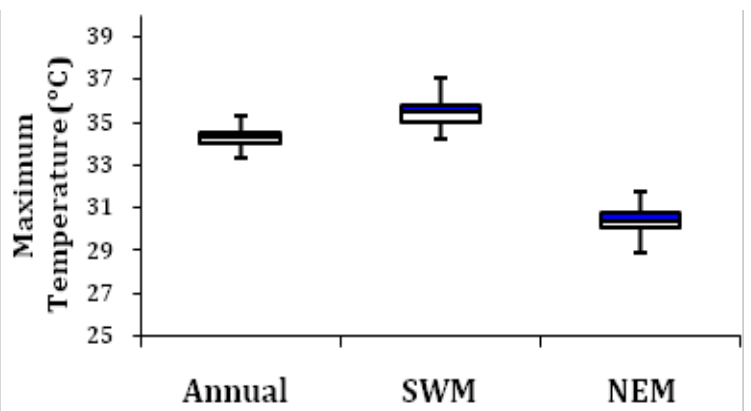

A) Maximum temperature of Tiruchirappalli

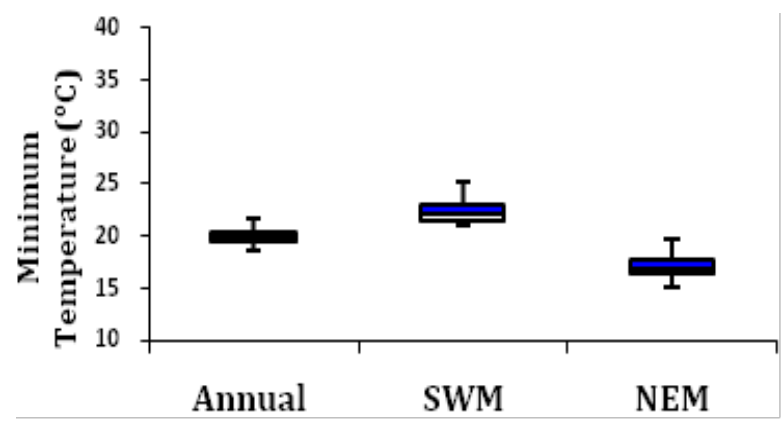

B) Minimum Temperature of Tiruchirappall

Figure 2. Maximum and Minimum temperature of Tiruchirappalli

\subsection{Anticipated changes in future climate of Tiruchirappalli}

3.2.1 Temperature: Maximum and minimum temperature of was projected to increase by the model studied. Though variation in magnitude exist between the scenarios (RCP4.5 and RCP8.5). both projected an increment for maximum and minimum temperatures during mid-century time scale. probably due to increased concentration of greenhouse gases in the atmosphere as indicated by IPCC (2014).

Both. the stabilization scenario RCP 4.5 as well as the overshoot scenario RCP 8.5. projected an increase in temperature. Among the monsoons. increase in SWM is (RCP 4.5:1.7 ${ }^{\circ} \mathrm{C}$ and $\mathrm{RCP} 8.5: 2.5^{\circ} \mathrm{C}$ ) maximum temperature. which is comparatively lesser than that of NEM (RCP 4.5: $1.9^{\circ} \mathrm{C}$ and RCP 8.5: $2.9^{\circ} \mathrm{C}$ ) for projections through both the scenarios (Table. 1). For minimum temperature. the range of increase projected for SWM (RCP 4.5:1. $6^{\circ} \mathrm{C}$ and RCP $8.5: 2.2^{\circ} \mathrm{C}$ ). which is comparatively higher than that of temperature projections for NEM (RCP 4.5: $1.6^{\circ} \mathrm{C}$ and RCP 8.5: $2.1{ }^{\circ} \mathrm{C}$ ). A similar higher range of increase during SWM period was also reported by Kothawale and Rupakumar (2005); Rupakumar et al. (2006) over parts of India. 
The appreciable difference in the temperature projection between the monsoon seasons could also be attributed to the seasonal wind shifts during monsoon period and the nature of orography in Tamil Nadu (Jegankumar et al. 2012). Relative change in the magnitude of maximum and minimum temperature was compared. Interestingly. both the RCP scenario has projected a higher range of increase for maximum temperature than that of minimum temperature over Tiruchirappalli during mid-century.

3.2.2 Rainfall: Monsoon rainfall projection over Tiruchirappalli was studied as it plays vital role in rain fed agriculture of Tamil Nadu. Among the monsoons. irrespective of the scenarios. SWM is projected to have a decrease (RCP 4.5: $-1 \%$ and RCP $8.5:-11 \%$ ) and NEM is also projected to receive a decreased rainfall of 2 (RCP 4.5 ) and 14 per cent (RCP 8.5). The appreciable difference in the rainfall projection between the monsoon seasons could be attributed to the seasonal wind shifts during monsoon period and the nature of orography in Tamil Nadu (Jegankumar et al. 2012).

\begin{tabular}{|c|c|c|c|c|c|c|}
\hline \multirow{4}{*}{$\begin{array}{c}\text { Time } \\
\text { scale }\end{array}$} & \multicolumn{2}{|c|}{$\begin{array}{c}\text { Change in } \\
\text { Maximum } \\
\left({ }^{\circ} \mathbf{C}\right)\end{array}$} & \multicolumn{2}{c|}{$\begin{array}{c}\text { Change in } \\
\text { Minimum } \\
\left({ }^{\circ} \text { C) }\right.\end{array}$} & \multicolumn{2}{c|}{$\begin{array}{c}\text { Precipitation } \\
\text { Change (\%) }\end{array}$} \\
\cline { 2 - 7 } & $\begin{array}{c}\text { RCP } \\
\text { 4.5 }\end{array}$ & $\begin{array}{r}\text { RCP } \\
\mathbf{8 . 5}\end{array}$ & $\begin{array}{c}\text { RCP } \\
\mathbf{4 . 5}\end{array}$ & $\begin{array}{c}\text { RCP8 } \\
\text { RCP }\end{array}$ & $\begin{array}{c}\text { RCP8 } \\
\mathbf{4 n y y y y}\end{array}$ \\
\hline SWM & 1.7 & 2.5 & 1.6 & 2.2 & -1 & -11 \\
\hline NEM & 1.9 & 2.9 & 1.6 & 2.1 & -2 & -14 \\
\hline
\end{tabular}

Table 1. Future climatic projection based on RCP4.5 and RCP8.5 scenarios

3.3 Assessing the impact of Current climate variability and future climate projection On Water Use Efficiency of Tomato

Tomato productivity during Rabi season ranged from 31.4 to 42.2 with mean of $35.1 \mathrm{t} \mathrm{ha}^{-1}$ under current climate. WUE was varied from 54.7 to $73.9 \mathrm{~kg} \mathrm{ha}^{-1} \mathrm{~mm}^{-1}$ with the mean of $63.3 \mathrm{~kg}$ $\mathrm{ha}^{-1} \mathrm{~mm}^{-1}$. In RCP 4.5 scenario the tomato productivity and WUE is expected to decrease and tomato productivity was ranged from 24.7 to 37.1 with mean of $31.7 \mathrm{t} \mathrm{ha}^{-1}$. WUE was varied from 47.2 to $67.5 \mathrm{~kg} \mathrm{ha}^{-1} \mathrm{~mm}^{-1}$ with the mean of 59.90 $\mathrm{Kg} \mathrm{ha}^{-1} \mathrm{~mm}^{-1}$. In RCP 8.5 scenario the tomato productivity and WUE is expected to decrease and tomato productivity was ranged from 25.3 to 36.9 with mean of $30.6 \mathrm{t} \mathrm{ha}^{-1}$. WUE was varied from 46.4 to $71.5 \mathrm{Kg} \mathrm{ha}^{-1} \mathrm{~mm}^{-1}$ with the mean of 54.30 $\mathrm{Kg} \mathrm{ha}^{-1} \mathrm{~mm}^{-1}$. (Table 1.) These results are in harmony with the finding of Weiguang et al. (2012). Tomato and WUE was varied over 30 years. Tomato yield varied between -9.6 to -12.8 per cent and WUE varied between -5.3 and -14.2 per cent. (Table 2.) Different climatic conditions prevailed during cropping between the years might have influenced yield and WUE of tomato. Climate variability has been principal source of fluctuations in Indian food production. Even though there is no long-term trend. inter - annual variability of Indian monsoon rainfall leading to frequent droughts and floods has profound influence on agriculture (Rajeevan and Pie. 2006)

\begin{tabular}{|c|c|c|c|c|c|c|c|}
\hline \multirow{2}{*}{$\begin{array}{c}\text { Years } \\
(1980- \\
2009)\end{array}$} & \multicolumn{2}{|c|}{$\begin{array}{l}\text { Current } \\
\text { climate }\end{array}$} & \multirow{2}{*}{$\begin{array}{l}\text { Years } \\
(2040- \\
2069)\end{array}$} & \multicolumn{2}{|c|}{ RCP 4.5} & \multicolumn{2}{|c|}{ RCP 8.5} \\
\hline & Yield & WUE & & Yield & $\begin{array}{c}\text { WU } \\
\mathbf{E}\end{array}$ & $\begin{array}{c}\text { Yiel } \\
\text { d }\end{array}$ & $\begin{array}{c}\text { WU } \\
\mathbf{E}\end{array}$ \\
\hline
\end{tabular}

\begin{tabular}{|c|c|c|c|c|c|c|c|}
\hline 1980 & 32.6 & 57.4 & 2040 & 35.8 & 67.4 & 30.1 & 50 \\
\hline 1981 & 33.4 & 60.6 & 2041 & 33.8 & 67.5 & 29.7 & 54.2 \\
\hline 1982 & 32.6 & 64.5 & 2042 & 24.7 & 47.2 & 25.3 & 48.9 \\
\hline 1983 & 38.2 & 70.2 & 2043 & 33.8 & 58.1 & 32.9 & 57.2 \\
\hline 1984 & 38.2 & 62.1 & 2044 & 30.6 & 59.6 & 35.3 & 55.1 \\
\hline 1985 & 31.4 & 57.8 & 2045 & 30.9 & 62.1 & 27.7 & 51.1 \\
\hline 1986 & 33.0 & 62.4 & 2046 & 30.1 & 57.4 & 26.9 & 50.9 \\
\hline 1987 & 33.0 & 54.7 & 2047 & 37.1 & 67.1 & 30.9 & 51.8 \\
\hline 1988 & 35.0 & 60.8 & 2048 & 34.9 & 62.7 & 29.7 & 46.4 \\
\hline 1989 & 37.0 & 68.1 & 2049 & 29.3 & 57.0 & 31.3 & 57.4 \\
\hline 1990 & 33.0 & 57.9 & 2050 & 29.3 & 58.1 & 30.9 & 50.4 \\
\hline 1991 & 35.8 & 67.3 & 2051 & 27.4 & 52.1 & 30.5 & 54.7 \\
\hline 1992 & 37.4 & 73.7 & 2052 & 33.3 & 62.5 & 30.5 & 56.2 \\
\hline 1993 & 32.2 & 62.0 & 2053 & 28.1 & 52.5 & 31.3 & 60.3 \\
\hline 1994 & 33.0 & 58.1 & 2054 & 32.0 & 54.5 & 28.9 & 51.5 \\
\hline 1995 & 36.2 & 63.3 & 2055 & 36.6 & 64.6 & 27.3 & 49.1 \\
\hline 1996 & 38.6 & 66.9 & 2056 & 31.4 & 60.0 & 32.9 & 54.4 \\
\hline 1997 & 34.6 & 61.6 & 2057 & 32.1 & 56.1 & 30.5 & 57.4 \\
\hline 1998 & 37.8 & 64.2 & 2058 & 33.1 & 60.8 & 31.3 & 54.3 \\
\hline 1999 & 32.6 & 57.7 & 2059 & 32.6 & 65.4 & 30.5 & 52.8 \\
\hline 2000 & 35.4 & 68.6 & 2060 & 27.5 & 54.8 & 29.3 & 55.6 \\
\hline 2001 & 35.8 & 61.5 & 2061 & 35.6 & 59.8 & 33.3 & 58.2 \\
\hline 2002 & 31.4 & 57.8 & 2062 & 28.0 & 56.7 & 27.7 & 48.6 \\
\hline 2003 & 33.0 & 61.3 & 2063 & 26.2 & 66.3 & 28.5 & 51.5 \\
\hline 2004 & 36.2 & 68.7 & 2064 & 31.6 & 60.4 & 28.1 & 50.7 \\
\hline 2005 & 36.2 & 64.4 & 2065 & 35.1 & 62.4 & 32.9 & 60.2 \\
\hline 2006 & 36.6 & 66.0 & 2066 & 34.7 & 64.0 & 31.3 & 57.3 \\
\hline 2007 & 37.4 & 64.5 & 2067 & 35.0 & 62.0 & 32.5 & 56 \\
\hline 2008 & 42.2 & 73.9 & 2068 & 28.0 & 59.0 & 32.1 & 54.7 \\
\hline 2009 & 34.2 & 60.4 & 2069 & 31.3 & 59.3 & 36.9 & 71.5 \\
\hline Mean & $\mathbf{3 5 . 1}$ & $\mathbf{6 3 . 3}$ & & $\mathbf{3 1 . 7}$ & $\mathbf{5 9 . 9}$ & $\mathbf{3 0 . 6}$ & $\mathbf{5 4 . 3}$ \\
\hline & & & & & & & \\
\hline
\end{tabular}

Table 2. Tomato productivity and WUE for the current (19802009 ) and future (2040 - 2069) climate (RCP 4.5 and RCP 8.5) in Rabi season

Results showed that future climate would negatively impact the tomato productivity and WUE. As per future projections tomato yield is expected to decrease in the range of 9.6 to 12.8 per cent with the mean decrease of 11.2 per cent. WUE is expected to decrease between 5.3 and 14.2 with the mean of 9.7 per cent. In the future WUE reduced might be due to higher crop water requirement $(\mathrm{ET})$ with fewer yields under warming conditions. These results are in harmony with the finding of Weiguang et al. (2012). Doll (2002) found increases in evaporative demands lead to increase the need for irrigation worldwide, with relative changes in total, about $+5-8$ per cent by 2070 . Studies undertaken by Chattopadhyay and Hulme (1997) for Indian subcontinent indicated likely increase of potential evapotranspiration for future warming. The current investigation indicates that extreme rainfall situations such as deficit and excess conditions are affecting the tomato yield and water productivity. Optimization of irrigation through analysing the response of tomato to deficit and excess rainfall conditions could improve the yield and WUE of tomato.

\section{Conclusion}

Future climate would negatively impact the tomato productivity and WUE. As per RCP 8.5 scenario, tomato yield is expected to decrease in the range of 12.6 to 19.4 per cent with the mean decrease of 13 per cent. WUE is expected to decrease between 
3.3 and 15.1 with the mean of 14.3 per cent. In the future WUE reduced might be due to higher crop water requirement (ET) with fewer yields under warming conditions.

\section{References}

Chattopadhyay, N. and Hulme, M. 1997. Evaporation and potential evapotranspiration in India under conditions of recent and future climate change: Journal of Agricultural and Forest Meteorology, 87(1), pp. 55-73.

Doll, P. 2002. Impact of climate change and variability on irrigation requirements: A global perspective. Climatic Change, 54(3), pp. 269-293.

Fereres, E. and Soriano, M.A. 2007. Deficit irrigation for reducing agricultural water use: Journal Environmental and Experimental Botany, 58, pp. 147-59.

IPCC. 2014. In: Edenhofer, O., Pichs-Madruga, R., Sokona, Y., Farahani, E., Kadner, S., Seyboth, K., Adler, A., Baum, I., Brunner, S., Eickemeier, P., Kriemann, B., Savolainen, J., Schlömer, S., Von Stechow, C., Zwickel, T., Minx, J.C. (Eds.), Climate Change 2014: Mitigation of Climate Change Contribution of Working Group III to the Fifth Assessment: Report of the Intergovernmental Panel on Climate Change. Cambridge University Press, Cambridge, United Kingdom and New York, NY, USA https://www.ipcc.ch/pdf/assessmentreport/ar5/wg3/ ipcc_wg3_ar5_full.pdf (Accessed 20 October 2016).

Jegankumar, R., Nagarathinam, S. R. and Kannadasan, K. 2012. Spatial distribution of rainfall in Salem and Namakkal districts: International Journal of Geomatics and Geosciences, $(2,4)$, pp. 976-994.

Kothawale, D. R. and Rupa Kumar, K. 2005. On the recent changes in surface temperature trends over India: Geophysical Research Letters, (32), L18714.

Rajeevan, M and Pai, D.S. 2006. El-Nino Indian monsoon predictive relationships. National Climate Centre Research Report

Rosegrant Mark, W., Ximing Cal and Sarah Cline, A. 2002. In World water and food to 2025: Dealing with scarcity, International Food Policy Research Institute. Washington, D.C.

Rupa Kumar, K., Sahai, A. K., Krishna Kumar, K., Patwardhan, S. K., Mishra, P. K., Revadekar, J. V., Kamala, K and Pant, G. B. 2006. "High-resolution climate change scenarios for India for the 21st century": Current Science journal, (90), pp. 334-345.

Weiguang, W., Fengchao, S., Yufeng, L and Junzeng, Xu. 2012. Changes of Rice Water Demand and Irrigation Water Requirement in Southeast China under Future Climate change: Procedia Engineering, (28), pp. 341-345. 